Iwona Zaporowska-Stachowiak ${ }^{1,2}$, Mary-Tiffany Adannia Oduah³ ${ }^{3}$ Magdalena Celichowska4, Gabriela Dziuba ${ }^{4}$, Anna Mikołajczak ${ }^{4}$, Maria Perlińska ${ }^{4}$, Martyna Woźniak', Lidia Gorzelinska², Maciej Sopata ${ }^{2}$

${ }^{1}$ Chair and Department of Palliative Medicine, Poznan University of Medical Sciences

${ }^{2}$ Palliative Medicine In-Patient Unit, University Hospital of Lord's Transfiguration, Poznan University of Medical Sciences

${ }^{3}$ English Students' Research Association, Poznan University of Medical Sciences

${ }^{4}$ Students' Scientific Society, Poznan University of Medical Sciences

\title{
Opioids in clinical practice
}

\section{Abstract}

The treatment of pain improves quality of life. Opioids are commonly prescribed painkillers. The side effects of opioids depend on the route of administration, dosage, drug metabolism, comorbid diseases and the patient's general condition. Despite many beneficial effects, opioids can lead to increased mortality in heart failure, myocardial infarction, pulmonary oedema, and COPD. This article reviews specific uses of opioid medications. Opioids induce immunosuppression, and may undergo drug-drug interactions, especially during polytherapy or polypragmasia.

Palliat Med Pract 2019; 13, 4: 221-228

Key words: adverse effects, analgesia, morphine, opioids, pain management

\section{Introduction}

Opioids include all substances that act on opioid receptors: natural opiates, semisynthetic alkaloids derived from the opium poppy, their synthetic derivatives and endogenous peptides. Natural opiates comprise the following: codeine, morphine, oripavine, pseudomorphine, and thebaine. Semisynthetic opioids include oxycodone hydromorphone, oxymorphone, hydrocodone, and heroine. Synthetic opioids are chemically designed to mimic naturally occurring substances, and they comprise tramadol, fentanyl, buprenorphine, tapentadol, methadone, levorphanol, propoxyphene, loperamide, and pethidine (meperidine). Endogenous opioids include endorphins, enkephalins, dynorphins, and endomorphins. Precursor proteins and endomorphins have been found in the central nervous system in areas that have been involved in pain modulation, playing a role in stressful conditions such as pain. Opioids may act as agonists, partial agonists, or antagonists on their receptors $[1,2]$.

Opioid receptor types include the following: $\mu$ opioid receptor (MOR), $\delta$ opioid receptor (DOR), $\kappa$ opioid receptor (KOR), and opioid receptor-like 1 (ORL-1). MOR has the highest affinity for endorphins and is responsible for analgesic, physical dependence, respiratory depression, miosis, euphoria, and reduced gastrointestinal motility. Receptor $\delta$ has the highest affinity for enkephalins and function for analgesia, antidepressant and convulsant effects and physical dependence. Receptor $\kappa$ has the highest affinity for dynorphins and is responsible for: analgesia, depression, diuresis, miosis, sedation, anticonvulsant and dissociative effects. ORL- 1 exhibits the highest affinity for nociceptin. It is responsible for: anxiety, depression, learning, and Parkinsonism. Opioid receptors are present in the brain, spinal medulla and intramural nerve plexuses of alimentary and urogenital tract.

\footnotetext{
Address for correspondence:

Iwona Zaporowska-Stachowiak

Chair and Department of Palliative Medicine, Poznan University of Medical Sciences

e-mail: iwozapor@ump.edu.pl
} 


\section{Mechanism of action of opioids}

Opioid agonists bind to specific $G$ protein-coupled receptors (GPCRs) and modulate intracellular $\mathrm{Ca}^{2+}$ deposition. They close $\mathrm{Ca}^{2+}$ channels on presynaptic nerve terminals, inhibiting neurotransmitter release (e.g. glutamate), and inhibit postsynaptic neurons by opening $\mathrm{K}^{+}$channels [3]. Physiologic effects are strictly dependent on receptor type. All types of opioid receptors are located in the dorsal horn of the spinal cord (on pain transmission neurons and on the primary afferents that relay pain massage to them). Opioids inhibit dorsal horn pain transmission and the release of excitatory transmitters from primary afferents. Opioid agonists act on ascending as well as descending pathways.

Opioids exert both stimulatory and inhibitory effects on various functions [1]. They stimulate the vagal centre, chemoreceptors in the area postrema (followed by nausea and vomiting at the onset of treatment), oculomotor centre, antinociceptive system, smooth muscle in the gastrointestinal tract (followed by delayed gastric emptying and spastic constipation), as well as in the biliary and urinary tract (followed by impaired micturition). On the other hand, opioids suppress pain sensation, alertness, cough reflex, and respiratory (risk of respiratory depression) and emetic centres (anti-emetic effect induced by repeated doses of opioids) (Fig. 1) Opioids may also cause:

- Bradycardia (meperidine as an exception causes tachycardia via antimuscarinic action) and hypotension;

- Decreased renal blood flow;

- Decreased uterine contractility;

- Stimulation of anti-diuretic hormone (ADH), prolactin, and somatotropin release and inhibition of luteinising hormone release;

- Histamine release from mast cells resulting in skin flushing, warming, sweating and itching;

- Immunosuppression.

Use of opioid medications carries a risk of development of tolerance, and psychological and physical dependence.

\section{Indications for opioids}

Indications for opioids are presented in Table 1 [1, 4]. During pregnancy, opioids can cross, the placenta, and thus they can affect the foetus. Use of opioids may prolong labour by reducing uterine tone [1]. In biliary and renal colic opioids might increase tension of smooth muscles thereby increasing pain. In such cases, higher doses of opioids must be administered in order to successfully manage the pain [1]. In acute pulmonary oedema intravenous morphine is used in order to reduce anxiety, cardiac preload, and after- load (Table 1). Morphine is especially useful in the treatment of myocardial ischaemia with pulmonary oedema (with furosemide).

Opioids, e.g. buprenorphine, codeine, hydromorphone, methadone, morphine, oxycodone, and tramadol, are used in the treatment of patients diagnosed with cancer and non-cancer pain [5]. Use of oral morphine or fentanyl transdermal patches is common in treating pain in cancer patients (Table 1) [6]. In chronic pain management, frequent monitoring and urine screens should be performed [7]. Other indications for opioids include dyspnoea, cough, diarrhoea, general anaesthesia, regional analgesia, and drug withdrawal. For intubated and ventilated patients, sedation is achieved with the use of intravenous fentanyl, sufentanyl, morphine, or midazolam [8].

Codeine is used in the treatment of chronic cough; however, accumulation of mucus may occur leading to airway obstruction. In the treatment of diarrhoea, diphenoxylate and loperamide are used because they exert fewer CNS effects compared to crude opium. Meperidine which acts on 2 adrenoceptor is the most effective opioid to reduce shivering. For general anaesthesia, opioids are used for their analgesic, anxiolytic, and sedative properties. Opioids reduce cardiovascular depression during high-risk surgeries [1].

In regional analgesia, opioids are administered into the epidural or subarachnoid spaces of the spinal cord. Pruritus occurs in almost $50 \%$ of patients who receive intrathecal opioids [9]. Regional analgesia with opioids is also indicated for patients in intensive care units because they provide superior pain control and have fewer side effects than systemic treatment [10]. Opioids reduce the sensitivity of neurons in the respiratory centres; this dampens ventilatory response, and thus morphine is used in symptomatic treatment of dyspnoea.

Titration of opioids allows the determination of the dose at which shortness of breath is reduced without inhibition of the respiratory centre - commonly used morphine at a single dose of $2.5-5 \mathrm{mg}$ (orally). The drug can also be administered via inhalation. Morphine causes reduction of respiratory volume, reduced response to hypercapnia, reduced oxygen consumption, and increased effort tolerance in COPD patients [11-13]. Methadone, buprenorphine, and buprenorphine combined with naloxone are used in the treatment of patients with opioid drug dependence (Table 1) $[1,14]$.

\section{Drug-drug interactions}

Opioid analgesics might undergo drug-drug interactions especially in patients who are being co-ad- 
Table 1. Routes of drug administration and indications for opioids [8, 15-18]

\begin{tabular}{|c|c|c|c|c|}
\hline Opioid & Formulation & $\begin{array}{l}\text { Route of } \\
\text { administra- } \\
\text { tion }\end{array}$ & Indications & Comments \\
\hline \multirow[t]{5}{*}{ Tramadol } & $\begin{array}{l}\text { Immediate-release } \\
\text { and modified-rele- } \\
\text { ase tablets }\end{array}$ & Oral & \multirow[t]{5}{*}{$\begin{array}{l}\text { Pain especially with neuropathic } \\
\text { component }\end{array}$} & \multirow{5}{*}{$\begin{array}{l}\text { Drug-drug interactions } \\
\text { Risk of serotonin syndrome } \\
\text { when co-administered with } \\
\text { metoclopramide, selective } \\
\text { serotonin reuptake inhibitors, } \\
\text { linezolid, monoamine oxidase } \\
\text { inhibitors }\end{array}$} \\
\hline & Solution & IV, SC, IM & & \\
\hline & Suppository & Rectal & & \\
\hline & Drops & Oral & & \\
\hline & Capsule & Oral & & \\
\hline Codeine & $\begin{array}{l}\text { Syrup, Solution, } \\
\text { Tablets }\end{array}$ & Oral & Cough, diarrhoea & $10 \%$ is metabolised to morphine \\
\hline \multirow[t]{7}{*}{ Morphine } & $\begin{array}{l}\text { Solution (injecta- } \\
\text { ble) }\end{array}$ & $\begin{array}{l}\text { IV, SC, ED, } \\
\text { PVB, spinally } \\
\text { (spinal form } \\
\text { for PVB, ED, } \\
\text { spinal) }\end{array}$ & $\begin{array}{l}\text { Acute pulmonary oedema, pain } \\
\text { (also in liver impairment), } \\
\text { general anaesthesia (adjunct) } \\
\text { myocardial infarction }\end{array}$ & Start low, go slow \\
\hline & $\begin{array}{l}\text { Gauze pad with } \\
\text { solution from } \\
\text { ampule }\end{array}$ & Topical & Ulceration, pressure sores & $\begin{array}{l}\text { Systemic absorption may be } \\
\text { substantial }\end{array}$ \\
\hline & $\begin{array}{l}\text { Nebuliser with } \\
\text { solution from } \\
\text { ampules }\end{array}$ & Aerosol & COPD, dyspnoea & $\begin{array}{l}\text { Conflicting data referred to } \\
\text { effectiveness }\end{array}$ \\
\hline & Solution & Oral & $\begin{array}{l}\text { mucositis, moderate-severe } \\
\text { pain, cough }\end{array}$ & $\begin{array}{l}\text { when used topically significant } \\
\text { systemic absorption possible }\end{array}$ \\
\hline & $\begin{array}{l}\text { Immediate-release } \\
\text { and modified-re- } \\
\text { lease (12-h and } \\
24-\mathrm{h}) \text { tablets }\end{array}$ & Oral & Moderate-severe pain & Start low, go slow \\
\hline & Suppository & Rectal & Pain & Start low, go slow \\
\hline & $2 \%$ gel & Topical & $\begin{array}{l}\text { Wound and ulcer treatment, } \\
\text { mucositis }\end{array}$ & $\begin{array}{l}\text { Substantial systemic absorption } \\
\text { may pose significant risk. } \\
\text { Good pain control with limited } \\
\text { side effects. }\end{array}$ \\
\hline \multirow[t]{5}{*}{ Fentanyl } & Patch & TD & \multirow[t]{5}{*}{$\begin{array}{l}\text { Pain (also in renal impairment } \\
\text { and dialysed patients) }\end{array}$} & $\begin{array}{l}\text { Onset of action: } 12 \mathrm{~h} \text {; full effect: } \\
\text { after } 72 \mathrm{~h} \\
\text { Termination of action: } 12 \mathrm{~h} \text { after } \\
\text { withdrawal }\end{array}$ \\
\hline & Solution & IV & & $\begin{array}{l}\text { Treatment of severe pain in an } \\
\text { inpatient setting, when rapid } \\
\text { pain relief is needed }\end{array}$ \\
\hline & Nasal spray & Intranasally & & Breakthrough pain \\
\hline & Tablets & $\begin{array}{l}\text { Sublingual } \\
\text { or buccal }\end{array}$ & & Breakthrough pain \\
\hline & Lozenge/Lollipop & $\begin{array}{l}\text { Buccal, } \\
\text { transmu- } \\
\text { cosal }\end{array}$ & & Breakthrough pain \\
\hline \multirow[t]{3}{*}{$\begin{array}{l}\text { Buprenor- } \\
\text { phine }\end{array}$} & Patch & $\begin{array}{l}\text { Transdermal } \\
\text { system }\end{array}$ & \multirow{3}{*}{$\begin{array}{l}\text { Pain especially with neuropathic } \\
\text { component (also in renal im- } \\
\text { pairment and dialyzed patients) }\end{array}$} & \multirow[t]{3}{*}{ Opioid dependence in addicts } \\
\hline & Solution & Intravenous & & \\
\hline & Tablet & Sublingual & & \\
\hline \multirow[t]{2}{*}{ Oxycodone } & $\begin{array}{l}\text { Modified-release } \\
\text { tablets }\end{array}$ & Oral & Pain & \multirow[t]{2}{*}{ Less side effects than morphine } \\
\hline & Solution & $\begin{array}{l}\text { IV, ED, spi- } \\
\text { nally }\end{array}$ & & \\
\hline
\end{tabular}


Table $1 \mathrm{~cd}$. Routes of drug administration and indications for opioids [8, 15-18]

\begin{tabular}{|c|c|c|c|c|}
\hline Opioid & Formulation & $\begin{array}{l}\text { Route of } \\
\text { administra- } \\
\text { tion }\end{array}$ & Indications & Comments \\
\hline $\begin{array}{l}\text { Oxycodo- } \\
\text { ne/ } \\
\text { Naloxone }\end{array}$ & $\begin{array}{l}\text { Modified-release } \\
\text { tablets }\end{array}$ & Oral & $\begin{array}{l}\text { Pain in patients with opioid-in- } \\
\text { duced constipation refractory to } \\
\text { laxatives }\end{array}$ & \\
\hline Tapentadol & $\begin{array}{l}\text { Immediate-release } \\
\text { and modified-rele- } \\
\text { ase tablets }\end{array}$ & Oral & $\begin{array}{l}\text { Pain especially with neuropathic } \\
\text { component }\end{array}$ & \\
\hline Pethidine & Solution & IV, IM, SC & & $\begin{array}{l}\text { Parasympatholytic activity indi- } \\
\text { cated in colic pain. } \\
\text { Metabolised to neurotoxic nor- } \\
\text { pethidine (not for chronic use) }\end{array}$ \\
\hline $\begin{array}{l}\text { Methado- } \\
\text { ne }\end{array}$ & Syrup, tablet & Oral & $\begin{array}{l}\text { Treatment of addiction to other } \\
\text { opioids, moderate to severe } \\
\text { pain (effective in neuropathic } \\
\text { pain), cough }\end{array}$ & $\begin{array}{l}\text { Metabolism and T1/2 great } \\
\text { individual variation - careful } \\
\text { titration needed. } \\
\text { T1/2 of single dose }=4-6 \mathrm{~h} \\
\text { when given parenterally, } 12-18 \\
\mathrm{~h} \text { orally; repeated doses }= \\
12-48 \mathrm{~h} \text { [1]. } \\
\text { Good alternative for patients } \\
\text { who are being given high opioid } \\
\text { doses [2] }\end{array}$ \\
\hline
\end{tabular}

ministered with large number of drugs (polytherapy, polypragmasia). Co-administration of certain drugs with opioids may cause CNS depression, increased sedation, and have an impact on the cardiovascular system. Monoamine oxidase inhibitors may evoke hyperpyrexic coma. Recently, it has been emphasised that concomitant use of opioids and anti-platelet P2Y12 oral inhibitors have a negative impact on thrombotic protection in acute coronary syndromes due to inhibition of gastric emptying caused by opioids and a delay in anti-platelet action of ADP-receptor inhibitors [1]. The effects of opioids on oral P2Y12 inhibitors are presented in Table 2.

\section{Contraindications and risk factors associated with the use of opioids}

In pain treatment there are no contraindications to use of opioids when titrated properly in palliative care patients [21]. There are contraindications in all the other patient populations as follows:

- Acute abdomen,

- Acute diarrhoea (Clostridium difficile induced),

- Acute hepatic disease,

- Gastroparesis,

- Paralytic ileus,

- MAO inhibitors use within the last two weeks,

- Head injury,

- Respiratory depression,

- Obstructive airway disease,

- Pheochromocytoma.
Opioids should be used with caution in the following circumstances:

- Adrenal gland insufficiency;

- Alcohol and/or drug abuse history;

- Asthma and COPD - patients with impaired pulmonary function - opioids may lead to acute respiratory failure. However, opioids are useful in the treatment of COPD and lung cancer because they relieve dyspnoea and pain. They are administered orally and parenterally [22];

- Biliary tract diseases;

- Constipation;

- Delirium;

- Epilepsy;

- Hypovolaemia followed by hypotension;

- Hypothyroidism;

- Inflammatory bowel disease;

- Pancreatitis;

- Prostatic hyperplasia;

- Use of pure agonists with weak partial agonists may lead to diminishing analgesia (whereas buprenorphine in appropriate doses provides analgesia);

- Patients with head injuries - carbon dioxide retention secondary to respiratory depression leads to intracranial vasodilation. In patients with elevated intracranial pressure lethal alterations in brain function may occur (concerning to palliative patients);

- During pregnancy the foetus may become physically dependent and manifest withdrawal symptoms (during labour single doses of pethidine are given); 
Table 2. Effects of opioid co-administration with oral anti-platelet P2Y12 inhibitors [19, 20]

\begin{tabular}{|c|c|c|c|c|c|}
\hline Drug & Activity & Activation & $\begin{array}{l}\text { Poten- } \\
\text { cy }\end{array}$ & Indications & $\begin{array}{l}\text { Impact of simultaneous use } \\
\text { with morphine on bioavaila- } \\
\text { bility }\end{array}$ \\
\hline Clopidogrel & Prodrug & $\begin{array}{l}\text { Hydrolysis by es- } \\
\text { terases to inactive } \\
(85 \%) \text { metabolite, } \\
\text { the rest }(15 \%)- \\
\text { two steps in the } \\
\text { liver via CYP2C19 } \\
\text { and CYP2C19 } \\
\text { - major and } \\
\text { paraoxonase-1 } \\
(\mathrm{PON}-1) \text { - minor }\end{array}$ & + & $\begin{array}{l}\text { Unstable angina. } \\
\text { NSTEMI in combination } \\
\text { with aspirin. } \\
\text { STEMI. } \\
\text { Recent myocardial } \\
\text { infarction. } \\
\text { Stroke. } \\
\text { Peripheral vascular } \\
\text { disease }\end{array}$ & $\begin{array}{l}\text { Irreversible inhibitor. } \\
\text { Morphine slows down clopi- } \\
\text { dogrel absorption, decreases } \\
\text { plasma levels of its active metab- } \\
\text { olite by } 34 \% \text {, delays and dimin- } \\
\text { ishes the effects of clopidogrel } \\
\text { on platelets in healthy volunteers }\end{array}$ \\
\hline Prasugrel & Prodrug & $\begin{array}{l}\text { Hydrolysis by } \\
\text { esterases, then } \\
\text { one step in the } \\
\text { liver via CYP3A4, } \\
\text { CYP2B6 } \\
\text { CYP2C19, CYP2C9 } \\
\text { and } \\
\text { CYP2D6 }\end{array}$ & ++ & $\begin{array}{l}\text { Acute coronary syn- } \\
\text { dromes. } \\
\text { Angina pectoris. } \\
\text { Myocardial infarction }\end{array}$ & $\begin{array}{l}\text { Irreversible inhibitor. } \\
\text { Morphine reduced maximal } \\
\text { plasma concentrations of prasug- } \\
\text { rel active metabolite by } 31 \% \text { and } \\
\text { delayed onset of maximal inhibi- } \\
\text { tion of platelet plug formation by } \\
10 \text { minutes }\end{array}$ \\
\hline Ticagrelor & Active & & +++ & $\begin{array}{l}\text { Acute coronary syn- } \\
\text { drome. } \\
\text { Myocardial infarction. } \\
\text { Cardiovascular events }\end{array}$ & $\begin{array}{l}\text { Reversible inhibitor. } \\
\text { Morphine decreases and delays } \\
\text { ticagrelor effects, but this does not } \\
\text { seem to decrease antiplatelet effects } \\
\text { in healthy volunteers. Morphine } \\
\text { delays ticagrelor absorption and } \\
\text { its active metabolite by } 1 \mathrm{~h} \text { and } \\
\text { decreases plasma levels of ticagrelor } \\
\text { and its active metabolite by } 25-31 \%\end{array}$ \\
\hline
\end{tabular}

- Patients with impaired hepatic or renal function morphine metabolites may accumulate. Morphine may be used in hepatic insufficiency; fentanyl, methadone, and buprenorphine in renal failure;

- Patients with endocrine disease: Addison's disease and myxoedema may present with prolonged and exaggerated responses to opioids. Decreased doses are required;

- Patient on opioids should not drive.

Risk factors of psychological dependence on to opioids:

- Family or personal history of substance abuse in the past;

- Young age;

- Legal problems in the past;

- High-risk environments;

- Problems with employers, family and friends in the past;

- Risk-taking and/or thrill-seeking behaviour;

- Cigarettes and stimulant use;

- Depression and/or anxiety in the past;

- History of childhood abuse;

- Multiple psychosocial stressors [23].

Chronic opioid administration may lead to tolerance development for analgesia accompanied by slow onset of tolerance to the side effects [24]. Tolerance to the use of opioids may be prevented by coadministration of ketamine [25].

\section{Opioids with dual mechanism of action}

Tapentadol acts as a $\mu$ opioid receptor agonist in the CNS and noradrenaline reuptake inhibitor in descending antinociceptive pathway, and is therefore useful in the treatment of both nociceptive and neuropathic pain. Tapentadol does not require metabolic activation, because it occurs only in one enantiomer.

Tramadol displays an agonist on $\mu$ opioid receptor, with lower affinity at $\delta$ and $\kappa$ receptors (40\% of activity). In addition, it inhibits reuptake of serotonin and noradrenaline in spinal cord (60\% of activity). Unlike tapentadol, it is metabolised in the liver to O-desmethyltramadol. It is generally safe and effective, however, co-administration with metoclopramide may precipitate seizures. In high doses, tramadol may also lead to serotonin syndrome.

\section{Opioids in a nutshell and controversies surrounding the use of selected opioids}

Codeine is a methylated form of morphine, present in small amounts in opium. It presents 10 times 
weaker analgesic effect than morphine because approximately $10 \%$ is demethylated in the liver to morphine which exerts proper analgesia. Codeine exhibits a central antitussive effect as well as weak sedative and analgesic functions via MOR in the brain. Indications for codeine treatment include dry persistent cough and moderate pain. Due to its inhibition of the cough reflex it is rather suited for treatment of non-productive cough [26]. Interestingly, the effectiveness of codeine in cough relief for patients with COPD is no greater than placebo [27].

Codeine, in combination with non-opioid analgesics such as paracetamol, aspirin or ibuprofen, can exert a much stronger analgesic effect. Codeine/paracetamol in adults has been shown to be effective and safe in acute and chronic nociceptive pain as well as in trauma patients. Particular care must be undertaken in the case of paediatric patients, as codeine can only be given to children over 12 years of age. In the case of using codeine/paracetamol in tonsillectomy the risk of genetic polymorphism (CYP450) should be assessed based on codeine metabolism related to CYP450 and its genetic variability [28].

Dihydrocodeine (DHC) is a semi-synthetic analogue of codeine and is twice as potent as codeine when used parenterally and slightly more powerful with oral use. In comparison to morphine it is six times weaker [29]. DHC belongs to group of weak opioids for mild to moderate pain (step 2 on the WHO analgesic ladder). It plays a role in the treatment of moderate, chronic pain as well as cough, diarrhoea, and opioid addiction [30, 31]. DHC displays superior analgesia, less fatigue, sleep disturbance, nausea, and vomiting, and better appetite in comparison to tramadol [32]. In some studies, single $30 \mathrm{mg}$ and $60 \mathrm{mg}$ doses of DHC did not provide desirable analgesia in postoperative pain whereas $400 \mathrm{mg}$ ibuprofen provided statistically superior analgesia [33]. DHC also works as a centrally acting cough suppressant, effective in cough alleviation in patients with lung cancer [34].

Morphine. The effect of morphine may be modified by co-administration of diclofenac and other drugs affecting UGT2B7 (the enzyme involved in glucuronidation of morphine - the main route of the drug metabolism). The minor route of morphine metabolism is mediated by CYP2D6; thus, substrates of the enzyme (amitriptyline, duloxetine, haloperidol, metoclopramide, ondansetron, oxycodone, paroxetine, risperidone, sertraline, tamoxifen, tramadol, trazodone, venlafaxine) can influence the effectiveness of morphine. CYP2D6 inhibitors (amiodarone, fluoxetine, haloperidol, methadone, paroxetine, sertraline) can increase the risk of adverse effects. Clinical importance of the above mentioned importance is unknown.
A number of studies have noted an increased mortality risk in heart failure patients receiving morphine [35-37]. Morphine provides analgesic benefits in patients with myocardial infarction, and it decreases blood pressure and anterior brachial mean pressure in these patients. The CRUSADE registry revealed higher rates of adverse clinical outcomes in patients with non-ST-segment elevation acute coronary syndromes (NSTEACS) treated with clopidogrel and concomitant intravenous morphine [38]. In STEMI patients, morphine has not been associated with a significant increase in major adverse cardiovascular events (MACE) [39]. However, significant interactions may occur with ticagrelor co-administration [40, 41]. In addition, there is slowed gastric emptying which may result in delayed clopidogrel absorption [42]. In patients with pulmonary oedema, morphine has been shown to increase 30-day mortality [36, 37, 43-45]. Vozoris et al. demonstrated increased adverse respiratory outcomes as well as mortality in patients with COPD [46]. Nevertheless, morphine improved respiratory function and exercise tolerance in these patients [47].

Oxycodone, an agonist at mu and kappa (effective in visceral pain) receptors is a substrate of CYP3A4 (major) and CYP2D6 (minor) and thus may undergo drug-drug interactions. Oxycodone may be used along with morphine and hydromorphone as a first line opioid for the treatment of moderate to severe pain in cancer patients [48-50]. In addition, oxycodone is recommended for the treatment of acute postoperative pain [51]. In hepatic or renal impairment oxycodone doses should be reduced.

Buprenorphine, a partial mu-receptor agonist, ORL-1 agonist and beta-receptor antagonist. However, at therapeutic doses buprenorphine acts as a full opioid receptor agonist because there is no ceiling effect of analgesia in doses up to $32 \mathrm{mg}$ daily [52]. Due to extensive glucuronidation and much less CYP3A4 metabolism, buprenorphine undergoes first-pass effect and little risk of drug-drug interactions. However, co-administration of haloperidol, levomepromazine or antihypertensives may cause hypotension. Other opioids (mu-receptor agonists) can increase the analgesic effect of buprenorphine. Buprenorphine is not recommended for the treatment of acute or intermittent pain in opioid-naive patients [25]. Buprenorphine has a beneficial ceiling effect for respiratory depression, resulting in respiratory depression only when administered in high doses.

Tapentadol exerts a dual mechanism of action; it acts as a $\mu$ opioid receptor (MOR) agonist in the CNS and noradrenaline reuptake inhibitor in descending antinociceptive pathway, and is therefore useful in the treatment of both nociceptive and neuropathic pain. 
Tapentadol does not require metabolic activation, because it occurs only in one enantiomer.

Methadone is metabolised by CYP3A4 and CYP2B6, and thus inhibitors of the enzymes (amiodarone, clarithromycin, diclofenac, diltiazem, high- dose fluconazole, haloperidol, verapamil or/and clopidogrel, fluoxetine, sertraline) can increase the risk of drug toxicity. Inducers of the enzymes (carbamazepine, clonazepam, dexamethasone, fentanyl, haloperidol, ketamine, midazolam, omeprazole, oxycodone, risperidone, venlafaxine, diclofenac, ketamine) can decrease the effectiveness of methadone. CYP1A2 and CYP2D6 are also involved in methadone metabolism, but to a lesser extent. Recently, an association between the use of methadone and the occurrence of arrhythmias, i.e. ventricular tachycardia (VT), has been discovered. The main mechanism of occurrence of VT is prolongation of the QT segment, therefore, methadone administration must be preceded by correction of electrolyte imbalance. If daily dosing is expected to exceed $100 \mathrm{mg}$ p.o., electrocardiogram monitoring is recommended [53].

\section{Conclusions}

1. Proper titration of the dose of opioids is crucial for avoiding respiratory depression inducible by these drugs.

2. Buprenorphine, at a therapeutic dose, acts as a $\mu$-opioid receptor agonist and may be co-administered with other $\mu$-opioid receptor agonists.

3. Co-administration of ketamine with opioids decreases the demand for opioids, thus necessitating decreased doses of opioids, and it prevents the development of opioid tolerance.

4. In renal impairment, fentanyl, buprenorphine or methadone should be used.

5. Topical formulations of morphine (solution, gel, gauze pad, aerosol) can minimise the risk of systemic adverse effects. When administered over large areas of the skin, wounds or mucous membranes, morphine can cause sedation.

6. Drug-drug and drug-food (grapefruit juice) interactions should be taken into consideration in patients concomitantly receiving CNS depressants, MAOIs, antihypertensives and antipsychotics and xenobiotics metabolised by CYP450 and glycoprotein $\mathrm{P}$ systems.

7. Opioid-induced delay in gastric emptying can limit or nullify the effect of anti-platelet drugs.

\section{References}

1. Katzung BG. Basic and Clinical Pharmacology. McGraw-Hill Medical 2012.

2. Drug Actions: Basic Principles and Therapeutic Aspects, Mutschler. Hartmut.
3. Liman AG, Gauthier ME. Pharmacology of oioid drugs (basic rinciles). In: Portenoy RK, Bruera E. ed. Toics in alliative care. Oxford University Press, New York 1997.

4. Coppes OJ, Sang CN. Indications for Opioid Antagonists. Curr Pain Headache Rep. 2017; 21(6): 30, doi: 10.1007/s11916017-0630-z, indexed in Pubmed: 28547246.

5. Leś J, Grzesiak J, Sokół-Kobielska E. Pain therapy Part V. Cancer pain article-4a89b590-2c7c-437d-8951-70aeaa89b807.

6. Wiffen PJ, Wee B, Derry $S$, et al. Opioids for cancer pain - an overview of Cochrane reviews. Cochrane Database Syst Rev. 2017; 7: CD012592, doi: 10.1002/14651858. CD012592.pub2, indexed in Pubmed: 28683172.

7. Jamison RN, Mao J. Opioid Analgesics. Mayo Clin Proc. 2015; 90(7): 957-968, doi: 10.1016/j.mayocp.2015.04.010, indexed in Pubmed: 26141334.

8. Gommers D, Bakker J. Medications for analgesia and sedation in the intensive care unit: an overview. Crit Care. 2008; 12 Suppl 3: S4, doi: 10.1186/cc6150, indexed in Pubmed: 18495055.

9. Rubio-Haro R, Morales-Sarabia J, Ferrer-Gomez C, et al. Regional analgesia techniques for pain management in patients admitted to the intensive care unit. Minerva Anestesiol. 2019; 85(10): 1118-1128, doi: 10.23736/503759393.19.13447-5, indexed in Pubmed: 30945513.

10. Jennings AL, Davies AN, Higgins JPT, et al. A systematic review of the use of opioids in the management of dyspnoea. Thorax. 2002; 57(11): 939-944, doi: 10.1136/thorax.57.11.939, indexed in Pubmed: 12403875.

11. Abernethy AP, Currow DC, Frith P, et al. Randomised, double blind, placebo controlled crossover trial of sustained release morphine for the management of refractory dyspnoea. BMJ. 2003; 327(7414): 523-528, doi: 10.1136/bmj.327.7414.523, indexed in Pubmed: 12958109.

12. Senderovich $H$, Yendamuri A. Management of Breathlessness in Palliative Care: Inhalers and Dyspnea-A Literature Review. Rambam Maimonides Med J. 2019; 10(1), doi: 10.5041/RMMJ.10357, indexed in Pubmed: 30332384.

13. Cohen B, Preuss CV. Opioid Analgesics [Updated 2019 Apr 3]. , indexed in Pubmed: 29083658.

14. Leppert W, Krajnik M, Wordliczek J. Delivery systems of opioid analgesics for pain relief: a review. Curr Pharm Des. 2013; 19(41): 7271-7293, doi: 10.2174/1381612819411312191 30127, indexed in Pubmed: 23489205.

15. Cohen B, Preuss CV. Opioid Analgesics. [Updated 2019 Apr 3]. , indexed in Pubmed: 29083658.

16. Miyazaki T, Satou S, Ohno T, et al. Topical morphine gel for pain management in head and neck cancer patients. Auris Nasus Larynx. 2014; 41(5): 496-498, doi: 10.1016/j. anl.2014.05.016, indexed in Pubmed: 24931629.

17. Giannopoulos G, Deftereos S, Kolokathis F, et al. P2Y12 Receptor Antagonists and Morphine: A Dangerous Liaison? Circ Cardiovasc Interv. 2016; 9(9), doi: 10.1161/CIRCINTERVENTIONS.116.004229, indexed in Pubmed: 27586412.

18. Anderson IB, Kearney TE. Use of methadone. West J Med. 2000; 172(1): 43-46, doi: 10.1136/ewjm.172.1.43, indexed in Pubmed: 10695444.

19. Cavallari LH, Jeong $H$, Bress A. Role of cytochrome P450 genotype in the steps toward personalized drug therapy. Pharmgenomics Pers Med. 2011; 4: 123-136, doi: 10.2147/PGPM. S15497, indexed in Pubmed: 23226058.

20. Dickman A. Drugs in Palliative Care. Oxford Medicine Online. 2012, doi: 10.1093/med/9780199660391.001.0001.

21. Jamison RN, Mao J. Opioid Analgesics. Mayo Clin Proc. 2015; 90(7): 957-968, doi: 10.1016/j.mayocp.2015.04.010, indexed in Pubmed: 26141334.

22. Dumas EO, Pollack GM. Opioid tolerance development: a pharmacokinetic/pharmacodynamic perspective. AAPS J. 2008; 10(4): 537-551, doi: 10.1208/s12248-008-9056-1, indexed in Pubmed: 18989788. 
23. Meine TJ, Roe MT, Chen AY, et al. CRUSADE Investigators. Association of intravenous morphine use and outcomes in acute coronary syndromes: results from the CRUSADE Quality Improvement Initiative. Am Heart J. 2005; 149(6): 1043-1049, doi: 10.1016/j.ahj.2005.02.010, indexed in Pubmed: 15976786.

24. Kao D, Bucher Bartelson B, Khatri V, et al. Trends in reporting methadone-associated cardiac arrhythmia, 1997-2011: an analysis of registry data. Ann Intern Med. 2013; 158(10): 735-740, doi: 10.7326/0003-4819-158-10-20130521000008, indexed in Pubmed: 23689766.

25. Brown R, Kraus C, Fleming M, et al. Methadone: applied pharmacology and use as adjunctive treatment in chronic pain. Postgrad Med J. 2004; 80(949): 654-659, doi: 10.1136/pgmj.2004.022988, indexed in Pubmed: 15537850.

26. Mattia C. Coluzzi, F. A look inside the association codeine-paracetamol: clinical pharmacology supports analgesic efficacy. Eur Rev Medical Pharmacological Sciences 2015; 19: 507-516. PMID. ; 25720726.

27. Leppert W. Dihydrocodeine as an opioid analgesic for the treatment of moderate to severe chronic pain. Curr Drug Metab. 2010; 11(6): 494-506, doi: 10.2174/138920010791636211, indexed in Pubmed: 20540693.

28. Leppert W, Majkowicz M. The impact of tramadol and dihydrocodeine treatment on quality of life of patients with cancer pain. Int J Clin Pract. 2010; 64(12): 1681-1687, doi: 10.1111/j.1742-1241.2010.02422.x, indexed in Pubmed: 20946274.

29. Robertson JR, Raab GM, Bruce M, et al. Addressing the efficacy of dihydrocodeine versus methadone as an alternative maintenance treatment for opiate dependence: A randomized controlled trial. Addiction. 2006; 101(12): 1752-1759, doi: 10.1111/j.1360-0443.2006.01603.x, indexed in Pubmed: 17156174.

30. Leppert W, Majkowicz M. The impact of tramadol and dihydrocodeine treatment on quality of life of patients with cancer pain. Int J Clin Pract. 2010; 64(12): 1681-1687, doi: 10.1111/j.1742-1241.2010.02422.x, indexed in Pubmed: 20946274.

31. Robertson JR, Raab GM, Bruce M, et al. Addressing the efficacy of dihydrocodeine versus methadone as an alternative maintenance treatment for opiate dependence: A randomized controlled trial. Addiction. 2006; 101(12): 1752-1759, doi: 10.1111/j.1360-0443.2006.01603.x, indexed in Pubmed: 17156174.

32. Edwards JE, McQuay HJ, Moore RA. Single dose dihydrocodeine for acute postoperative pain. Cochrane Database Syst Rev. 2000(4): CD002760, doi: 10.1002/14651858. CD002760, indexed in Pubmed: 11034754.

33. Bolser DC. Cough suppressant and pharmacologic protussive therapy: ACCP evidence-based clinical practice guidelines. Chest. 2006; 129(1 Suppl): 238S-249S, doi: 10.1378/chest.129.1_suppl.238S, indexed in Pubmed: 16428717.

34. Finnerup N, Attal N, Haroutounian S, et al. Pharmacotherapy for neuropathic pain in adults: a systematic review and meta-analysis. The Lancet Neurology. 2015; 14(2): 162-173, doi: 10.1016/s1474-4422(14)70251-0.

35. de Alencar Neto JN. Morphine, Oxygen, Nitrates, and Mortality Reducing Pharmacological Treatment for Acute Coronary Syndrome: An Evidence-based Review. Cureus. 2018; 10(1): e2114, doi: 10.7759/cureus.2114, indexed in Pubmed: 29581926.

36. Peacock WF, Hollander JE, Diercks DB, et al. Morphine and outcomes in acute decompensated heart failure: an ADHE$\mathrm{RE}$ analysis. Emergency Medicine Journal. 2008; 25(4): 205-209, doi: 10.1136/emj.2007.050419.

37. Miró Ò, Gil V, Peacock WF. Morphine in acute heart failure: good in relieving symptoms, bad in improving outcomes. J Thorac Dis. 2017; 9(9): E871-E874, doi: 10.21037/jtd.2017.08.22, indexed in Pubmed: 29221365.

38. Dahan A, Yassen A, Romberg $R$, et al. Buprenorphine induces ceiling in respiratory depression but not analgesia. Br J Anaesth. 2006; 96: 627-632, doi: 10.1093/bja/ael051, indexed in Pubmed: 16547090.

39. Bonin M, Mewton N, Roubille F, et al. CIRCUS Study Investigators. Effect and Safety of Morphine Use in Acute Anterior ST-Segment Elevation Myocardial Infarction. J Am Heart Assoc. 2018; 7(4), doi: 10.1161/JAHA.117.006833, indexed in Pubmed: 29440010.

40. Kubica J, Adamski P, Ostrowska M, et al. Morphine delays and attenuates ticagrelor exposure and action in patients with myocardial infarction: the randomized, double-blind, placebo-controlled IMPRESSION trial. Eur Heart J. 2016; 37(3): 245-252, doi: 10.1093/eurheartj/ehv547.

41. Meine TJ, Roe MT, Chen AY, et al. CRUSADE Investigators. Association of intravenous morphine use and outcomes in acute coronary syndromes: results from the CRUSADE Quality Improvement Initiative. Am Heart J. 2005; 149(6): 1043-1049, doi: 10.1016/j.ahj.2005.02.010, indexed in Pubmed: 15976786.

42. Hobl EL, Stimpfl T, Ebner J, et al. Morphine decreases clopidogrel concentrations and effects: a randomized, double-blind, placebo-controlled trial. J Am Coll Cardiol. 2014; 63(7): 630-635, doi: 10.1016/j.jacc.2013.10.068, indexed in Pubmed: 24315907.

43. Iakobishvili Z, Cohen E, Garty M, et al. Heart Failure Survey in Isarel (HFSIS) Investigators. Use of intravenous morphine for acute decompensated heart failure in patients with and without acute coronary syndromes. Acute Card Care. 2011; 13(2): 76-80, doi: 10.3109/17482941.2011.575165, indexed in Pubmed: 21627393.

44. Dominguez-Rodriguez A, Abreu-Gonzalez P. A critical appraisal of the morphine in the acute pulmonary edema: real or real uncertain? J Thorac Dis. 2017; 9(7): 1802-1805, doi: 10.21037/jtd.2017.06.58, indexed in Pubmed: 28839968.

45. Sosnowski MA. Review article: lack of effect of opiates in the treatment of acute cardiogenic pulmonary oedema. Emerg Med Australas. 2008; 20(5): 384-390, doi: 10.1111/j. 1742-6723.2008.01113.x, indexed in Pubmed: 18973635.

46. Vozoris NT, Wang X, Fischer HD, et al. Incident opioid drug use among older adults with chronic obstructive pulmonary disease: a population-based cohort study. Br J Clin Pharmacol. 2016; 81(1): 161-170, doi: 10.1111/bcp.12762, indexed in Pubmed: 26337922.

47. Abdallah SJ, Wilkinson-Maitland C, Saad N, et al. Effect of morphine on breathlessness and exercise endurance in advanced COPD: a randomised crossover trial. Eur Respir J. 2017; 50(4), doi: 10.1183/13993003.01235-2017, indexed in Pubmed: 29051274.

48. Caraceni A, Davies A, Poulain P, et al. Lancet Oncol. 2012; 13: 58-68.

49. Corli O, Forliani I, Roberto A, et al. Ann Oncol. 2016; 27: 1107-1115.

50. Rigamonti $\mathrm{Cl}$, Santini D, Maranzano $\mathrm{E}$, et al. Ann Oncol. 2012; 23(Suppl 7): 139-154.

51. Misiołek H, Zajączkowska R, Daszkiewicz A. Postoperative pain management - 2018. Anaesthesiol Intensive Ther. 2018.

52. Smith J, Owen E, Earis J, et al. Effect of codeine on objective measurement of cough in chronic obstructive pulmonary disease. J Allergy Clin Immunol. 2006; 117(4): 831-835, doi: 10.1016/j.jaci.2005.09.055, indexed in Pubmed: 16630941.

53. Bolser DC, Davenport PW. Codeine and cough: an ineffective gold standard. Curr Opin Allergy Clin Immunol. 2007; 7(1): 32-36, doi: 10.1097/ACl.0b013e3280115145, indexed in Pubmed: 17218808. 
Iwona Zaporowska-Stachowiak ${ }^{1,2}$, Mary-Tiffany Adannia Oduah ${ }^{3}$, Magdalena Celichowska ${ }^{4}$, Gabriela Dziuba ${ }^{4}$, Anna Mikolajczak ${ }^{4}$, Maria Perlińska ${ }^{4}$, Martyna Woźniak ${ }^{4}$, Lidia Gorzelinska², Maciej Sopata ${ }^{2}$

${ }^{1}$ Katedra i Klinika Medycyny Paliatywnej, Uniwersytet Medyczny im. Karola Marcinkowskiego w Poznaniu

${ }^{2}$ Oddział Medycyny Paliatywnej, Szpital Kliniczny Przemienienia Pańskiego, Uniwersytet Medyczny w Poznaniu

${ }^{3}$ English Students' Research Association, Uniwersytet Medyczny w Poznaniu

${ }^{4}$ Studenckie Towarzystwo Naukowe, Uniwersytet Medyczny w Poznaniu

\section{Opioidy w praktyce klinicznej}

Artykuł jest tłumaczeniem pracy: Zaporowska-Stachowiak I., Oduah M.-T. A., Celichowska M., Dziuba G., Mikolajczak A., Perlińska M., Woźniak M., Gorzelinska L., Sopata M., Opioids in clinical practice. Palliat. Med. Pract. 2019 tom 13, nr 4: $221-228$. Należy cytować wersję pierwotną.

Piśmiennictwo znajduje się na stronach 227-228.

\section{Streszczenie}

Leczenie bólu przyczynia się do poprawy jakości życia. Opioidy są powszechnie przepisywanymi lekami przeciwbólowymi. Działania niepożądane stosowania opioidów zależą od drogi podania, dawkowania, metabolizmu leków, chorób współistniejących i ogólnego stanu pacjenta. Pomimo wielu korzystnych efektów, opioidy mogą prowadzić do zwiększonej śmiertelności w przypadku wystąpienia niewydolności serca, zawału serca, obrzęku płuc i POChP. W niniejszym artykule omówiono poszczególne zastosowania leków opioidowych. Opioidy wywołują immunosupresję i mogą wchodzić w interakcje lekowe, zwłaszcza podczas politerapii lub polipragmazji.

Słowa kluczowe: działania niepożądane, analgezja, morfina, opioidy, leczenie bólu

Palliat Med Pract 2019; 13, 4: 229-236

\section{Wstęp}

Opioidy obejmują wszystkie substancje działające na receptory opioidowe: naturalne opiaty, półsyntetyczne alkaloidy maku, ich syntetyczne pochodne i endogenne peptydy. Naturalne opiaty obejmują: kodeinę, morfinę, oripawinę, pseudomorfinę, tebainę. Półsyntetyczne opioidy to: oksykodon, hydromorfon, oksymorfon, hydrokodon i heroina. Opioidy syntetyczne są modyfikowane chemicznie w taki sposób, aby odtworzyć naturalnie występujące substancje i obejmują tramadol, fentanyl, buprenorfinę, tapentadol, metadon, leworfanol, propoksyfen, loperamid i petydynę (meperydyna). Endogenne opioidy obejmują endorfiny, enkefaliny, dynorfiny i endomorfi- ny. Białka prekursorowe i endomorfiny występujące w ośrodkowym układzie nerwowym w obszarach, które uczestniczą $w$ regulacji bólu, odgrywają rolę w warunkach dużego stresu, takich jak ból. Opioidy mogą odgrywać rolę agonistów, agonistów częściowych lub antagonistów na swoich receptorach [1, 2].

Typy receptorów opioidowych obejmują: receptory opioidowe typu $\mu$ (MOR, $\mu$ opioid receptor), receptory opioidowe typu $\delta$ (DOR, $\delta$ opioid receptor), $\kappa$-receptory (KOR, $\kappa$ opioid receptor) i receptory opioid receptor-like (ORL-1). Receptor opioidowy typu $\mu$ charakteryzuje się największym powinowactwem do endorfin i jest odpowiedzialny za analgezję, fizyczne uzależnienie, depresję oddechową, miozę, euforię i zmniejszoną motorykę przewodu pokarmowego. Re-

\footnotetext{
Adres do korespondencji:

Iwona Zaporowska-Stachowiak

Katedra i Klinika Medycyny Paliatywnej,

Uniwersytet Medyczny im. Karola Marcinkowskiego w Poznaniu

e-mail: iwozapor@ump.edu.pl
} 
ceptor typu $\delta$ wykazuje najwyższe powinowactwo do enkefalin oraz funkcję przeciwbólową, przeciwdepresyjną, wywołującą drgawki oraz uzależnienie fizyczne. $\kappa$-receptor wykazuje najwyższe powinowactwo do dynorfin i jest odpowiedzialny za: analgezję, depresję, diurezę, miozę, sedację, działanie przeciwdrgawkowe i dysocjacyjne. Receptor ORL-1 wykazuje najwyższe powinowactwo do nocyceptyny. Odpowiada za: niepokój, depresję, przyswajanie wiedzy i parkinsonizm. Receptory opioidowe są obecne w mózgu, rdzeniu kręgowym i splotach nerwów wewnątrzoponowych przewodu pokarmowego i układu moczowo-płciowego.

\section{Mechanizm działania opioidów}

Agoniści opioidowi wiążą się ze specyficznymi receptorami sprzężonymi z białkami G (GPCR, G protein-coupled receptors) i modulują osadzanie wewnątrzkomórkowe Ca2 +. Zamykają one kanały Ca2+ na presynaptycznych końcówkach nerwowych, hamując uwalnianie neuroprzekaźników (np. glutaminianu), a także hamują neurony postsynaptyczne poprzez otwarcie kanałów K+ [3]. Efekty fizjologiczne są ściśle uzależnione od rodzaju receptora. Wszystkie rodzaje receptorów opioidowych znajdują się w rogu tylnym rdzenia kręgowego (na neuronach transmisyjnych i na pierwotnych neuronach aferentnych, które przekazują im informację dotyczącą odczuwanego bólu). Opioidy hamują transmisję z rogów tylnych rdzenia kręgowego i uwalnianie pobudzających przekaźników z pierwotnych neuronów aferentnych. Agoniści opioidowi działają zarówno na drogach wstępujących, jak i zstępujących.

Opioidy działają zarówno stymulująco, jak i hamująco na różne funkcje [1]. Pobudzają one nerw błędny, chemoreceptory w area postrema (po których na początku leczenia występują nudności i wymioty), ośrodek okulomotoryczny, układ antynocyceptywny, mięsień gładki w przewodzie pokarmowym (po którym następuje opóźnione opróżnianie żołądka i zaparcia spastyczne) oraz w drogach żółciowych i moczowych (po czym następuje upośledzenie funkcji oddawania moczu). Z drugiej strony opioidy zmniejszają odczuwanie bólu, czujność, odruch kaszlu, przyczyniają się do zaburzeń oddychania (ryzyko depresji oddechowej) oraz wpływają na ośrodek wymiotny (efekt przeciwwymiotny wywołany powtarzającymi się dawkami opioidów) (ryc. 1). Opioidy mogą również powodować:

- bradykardię (meperydyna jako jedyna powoduje tachykardię poprzez działanie przeciwmuskarynowe) i niedociśnienie;

- zmniejszony przepływ krwi w nerkach;
— zmniejszoną kurczliwość macicy;

- stymulację uwalniania hormonu antydiuretycznego $(A D H)$, prolaktyny i somatotropiny oraz hamowanie uwalniania hormonu luteinizującego;

- uwalnianie histaminy z komórek tucznych, powodujące zaczerwienienie skóry, nagrzewanie, pocenie się i świąd;

- Immunosupresja.

Stosowanie leków opioidowych niesie ze sobą ryzyko rozwoju tolerancji, uzależnienia psychicznego i fizycznego.

\section{Wskazania do stosowania opioidów}

Wskazania dotyczące stosowania opioidów przedstawiono w Tabeli 1 [1, 4]. W czasie ciąży opioidy mogą przenikać przez łożysko, co może oddziaływać na płód. Stosowanie opioidów może wydłużyć poród, zmniejszając napięcie macicy [1]. W przypadku kolek żółciowych i nerkowych, opioidy mogą zwiększać napięcie mięśni gładkich, co z kolei przyczynia się do nasilenia bólu. $W$ takim przypadku konieczne jest podanie większych dawek opioidów, aby skutecznie złagodzić ból [1]. W przypadku ostrego obrzęku płuc stosuje się morfinę dożylną w celu zmniejszenia uczucia niepokoju, obciążenia wstępnego i następczego serca (tab. 1). Morfina jest szczególnie pomocna w leczeniu niedokrwienia mięśnia sercowego z obrzękiem płuc (leczenie furosemidem).

Opioidy, na przykład buprenorfina, kodeina, hydromorfon, metadon, morfina, oksykodon, tramadol są stosowane w leczeniu pacjentów, u których rozpoznano nowotwór i ból nienowotworowy [5]. Stosowanie doustnej morfiny lub przezskórnych plastrów fentanylu jest powszechnie stosowane w leczeniu bólu u pacjentów chorych na nowotwory (tab. 1) [6]. W leczeniu przewlekłego bólu należy wykonywać częste kontrole i badania przesiewowe moczu [7]. Inne wskazania do zastosowania opioidów obejmują duszność, kaszel, biegunkę, znieczulenie ogólne, znieczulenie miejscowe oraz odstawienie leku. $U$ chorych intubowanych i wentylowanych sedację uzyskuje się, stosując dożylnie fentanyl, sufentanyl, morfinę lub midazolam [8].

Kodeinę stosuje się w leczeniu przewlekłego kaszlu, jednakże może wystąpić nagromadzenie śluzu prowadzące do niedrożności dróg oddechowych. W leczeniu biegunki stosuje się difenoksylat i loperamid, ponieważ mają one mniejszy wpływ na ośrodkowy układ nerwowy w porównaniu z surowym opium. Meperydyna działająca na receptor alfa-2-adrenergiczny jest najskuteczniejszym opioidem zmniejszającym drżenie. W znieczuleniu ogólnym opioidy stosuje się ze względu na ich właściwości przeciwbólowe, przeciwlękowe 
i uspokajające. Opioidy zmniejszają depresję sercowo-naczyniową podczas operacji wysokiego ryzyka [1].

W znieczuleniu miejscowym opioidy podawane są do przestrzeni zewnątrzoponowych lub podpajęczynówkowych rdzenia kręgowego. Świąd występuje u prawie $50 \%$ pacjentów, którzy otrzymywali opioidy dooponowo [9]. Znieczulenie miejscowe z zastosowaniem opioidów jest również wskazane w przypadku chorych przebywających na oddziałach intensywnej terapii, ponieważ zapewnia ono lepszą kontrolę bólu i ma mniej działań niepożądanych niż leczenie ogólnoustrojowe [10]. Opioidy zmniejszają wrażliwość neuronów w ośrodkach oddechowych, co osłabia czynność płuc, w związku z czym morfina jest stosowana w leczeniu objawowym duszności.

Miareczkowanie opioidów pozwala określić dawkę, przy której zmniejsza się duszność bez zahamowania pracy ośrodka oddechowego - powszechnie stosowanej morfiny w pojedynczej dawce $2,5-5 \mathrm{mg}$ (doustnie). Lek może być również stosowany do inhalacji. Morfina powoduje zmniejszenie objętości oddechowej, zmniejszoną odpowiedź na hiperkapnię, mniejsze zużycie tlenu oraz zwiększoną tolerancję wysitku u chorych na POChP [11-13]. Metadon, buprenorfina i buprenorfina w połączeniu z naloksonem są stosowane $w$ leczeniu pacjentów $z$ uzależnieniem od leków opioidowych (tab. 1) [1, 14].

\section{Interakcje lekowe}

Leki przeciwbólowe na bazie opioidów mogą wchodzić w interakcje lekowe, zwłaszcza u pacjentów, którzy są jednocześnie leczeni dużą liczbą leków (politerapia, polipragmazja). Jednoczesne stosowanie niektórych leków z opioidami może powodować depresję OUN, zwiększoną sedację i mieć wpływ na układ krążenia. Inhibitory monoaminooksydazy mogą wywoływać hiperpireksję. Ostatnio podkreśla się, że jednoczesne stosowanie opioidów i doustnych inhibitorów płytkowego receptora P2Y12 ma negatywny wpływ na ochronę przeciwzakrzepową w ostrych zespołach wieńcowych z powodu zahamowania opróżniania żołądka spowodowanego opioidami i opóźnienia $\mathrm{w}$ przeciwpłytkowym działaniu inhibitorów receptorów ADP [1]. Wpływ opioidów na doustne inhibitory P2Y12 przedstawiono w tabeli 2.

\section{Przeciwwskazania i czynniki ryzyka związane ze stosowaniem opioidów}

W procesie leczenia bólu nie ma przeciwwskazań do właściwego miareczkowania opioidów u pacjentów objętych opieką paliatywną [21]. U pozostałych pacjentów istnieją następujące przeciwwskazania:
- ostry brzuch,

- ostra biegunka (wywołana przez Clostridium difficile),

- ostra choroba wątroby,

- gastropareza,

- porażenna niedrożność jelita,

- stosowanie inhibitorów MAO w ciągu ostatnich 2 tygodni,

- uraz głowy,

- depresja oddechowa,

- obturacyjna choroba dróg oddechowych,

- guz chromochłonny nadnerczy.

Należy zachować ostrożność przy stosowaniu opio-

idów w następujących okolicznościach:

— niewydolność nadnerczy;

- nadużywanie alkoholu i/lub narkotyków w wywiadzie;

- astma i POChP - pacjenci z upośledzoną czynnością płuc - opioidy mogą prowadzić do ostrej niewydolności oddechowej. Jednak opioidy są skuteczne w leczeniu POChP i raka płuc, ponieważ łagodzą duszność i ból. Są one podawane doustnie i pozajelitowo [22];

- choroby dróg żółciowych;

- zaparcia;

- majaczenie;

- padaczka;

- hipowolemia, po której następuje niedociśnienie;

- niedoczynność tarczycy;

- nieswoiste zapalenie jelit;

- zapalenie trzustki;

- przerost prostaty;

- stosowanie czystych agonistów ze słabymi agonistami częściowymi może prowadzić do zmniejszenia analgezji (podczas gdy buprenorfina w odpowiednich dawkach zapewnia analgezję);

- pacjenci z urazami glowy - retencja dwutlenku węgla na skutek depresji oddechowej prowadzi do wewnątrzczaszkowej wazodilatacji. U pacjentów z podwyższonym ciśnieniem wewnątrzczaszkowym mogą wystąpić śmiertelne zmiany w funkcjonowaniu mózgu (dotyczy pacjentów paliatywnych);

- w czasie ciąży płód może uzależnić się fizycznie i przejawiać objawy odstawienia (podczas porodu podaje się pojedyncze dawki petydyny);

- pacjenci z upośledzoną czynnością wątroby lub nerek - możliwe nagromadzenie metabolitów morfiny. Morfina może być stosowana w niewydolności wątroby; fentanyl, metadon i buprenorfina w niewydolności nerek;

- pacjenci cierpiący na choroby endokrynologiczne: chorzy cierpiący na chorobę Addisona i obrzęk śluzowaty mogą wykazywać długotrwałe i przesadne reakcje na opioidy. Należy stosować zmniejszone dawki; 
Tabela 1. Drogi podawania leków i wskazania do stosowania opioidów [8, 15-18 ]

\begin{tabular}{|c|c|c|c|c|}
\hline Opioid & Formuła & Droga podania & Wskazania & Komentarze \\
\hline \multirow[t]{5}{*}{ Tramadol } & $\begin{array}{l}\text { Tabletki o natych- } \\
\text { miastowym uwal- } \\
\text { nianiu i tabletki } \\
\text { o zmodyfikowa- } \\
\text { nym uwalnianiu }\end{array}$ & Doustnie & \multirow[t]{5}{*}{$\begin{array}{l}\text { Ból, szczególnie w przypad- } \\
\text { ku czynnika neuropatycz- } \\
\text { nego }\end{array}$} & \multirow{5}{*}{$\begin{array}{l}\text { Interakcje lekowe } \\
\text { Ryzyko wystąpienia zespołu } \\
\text { serotoninowego w skojarzeniu } \\
\text { z metoklopramidem, selektyw- } \\
\text { nymi inhibitorami wychwytu } \\
\text { zwrotnego serotoniny, linezoli- } \\
\text { dem, inhibitorami monoamino- } \\
\text { oksydazy }\end{array}$} \\
\hline & Roztwór & $\begin{array}{l}\text { Dożylnie, podskór- } \\
\text { nie, domięśniowo }\end{array}$ & & \\
\hline & Czopek & Doodbytniczo & & \\
\hline & Krople & Doustnie & & \\
\hline & Kapsułka & Doustnie & & \\
\hline Kodeina & $\begin{array}{l}\text { Syrop, Roztwór, } \\
\text { Tabletki }\end{array}$ & Doustnie & Kaszel, biegunka & $\begin{array}{l}10 \% \text { jest metabolizowane do } \\
\text { morfiny. }\end{array}$ \\
\hline \multirow[t]{7}{*}{ Morfina } & $\begin{array}{l}\text { Roztwór (do } \\
\text { wstrzykiwania) }\end{array}$ & $\begin{array}{l}\text { Dożylnie, podskór- } \\
\text { nie, domięśniowo, } \\
\text { dokręgosłupowo } \\
\text { (dokręgosłupowo } \\
\text { w przypadku blo- } \\
\text { kady przykręgowej } \\
\text { PVB, ED, dokręgo- } \\
\text { słupowo) }\end{array}$ & $\begin{array}{l}\text { Ostry obrzęk płuc, ból (tak- } \\
\text { że w zaburzeniach czynno- } \\
\text { ści wątroby), } \\
\text { Znieczulenie ogólne (lek } \\
\text { uzupełniający) } \\
\text { zawał serca }\end{array}$ & Podawać stopniowo \\
\hline & $\begin{array}{l}\text { Gazik z roztwo- } \\
\text { rem z ampułki }\end{array}$ & Miejscowo & Owrzodzenie, odleżyny & $\begin{array}{l}\text { Wchłanianie ogólnoustrojowe } \\
\text { może być znaczne }\end{array}$ \\
\hline & $\begin{array}{l}\text { Nebulizator } \\
\text { z roztworem } \\
\text { z ampułek. }\end{array}$ & Aerozol & POChP, duszność & $\begin{array}{l}\text { Sprzeczne dane co do skutecz- } \\
\text { ności }\end{array}$ \\
\hline & Roztwór & Doustnie & $\begin{array}{l}\text { Zapalenie błony śluzowej, } \\
\text { ból umiarkowany-silny, } \\
\text { kaszel }\end{array}$ & $\begin{array}{l}\text { W przypadku stosowania miej- } \\
\text { scowego, możliwe jest znaczne } \\
\text { wchłanianie ogólnoustrojowe }\end{array}$ \\
\hline & $\begin{array}{l}\text { Tabletki o natych- } \\
\text { miastowym uwal- } \\
\text { nianiu i tabletki } \\
\text { o zmodyfikowa- } \\
\text { nym uwalnianiu } \\
\text { (12-godz. i 24- } \\
\text { godz.) }\end{array}$ & Doustnie & Ból umiarkowany-silny & Podawać stopniowo \\
\hline & Czopek & Doodbytniczo & Ból & Podawać stopniowo \\
\hline & Żel 2\% & Miejscowo & $\begin{array}{l}\text { Leczenie ran i wrzodów, } \\
\text { zapalenie błony śluzowej }\end{array}$ & $\begin{array}{l}\text { Znaczne wchłanianie ogól- } \\
\text { noustrojowe może stanowić } \\
\text { istotne ryzyko } \\
\text { Dobra kontrola bólu z ograni- } \\
\text { czoną ilością skutków ubocz- } \\
\text { nych }\end{array}$ \\
\hline \multirow[t]{5}{*}{ Fentanyl } & Plastry & Przezskórne & \multirow[t]{5}{*}{$\begin{array}{l}\text { Ból (również w przypadku } \\
\text { zaburzeń czynności nerek } \\
\text { i u pacjentów dializowa- } \\
\text { nych) }\end{array}$} & $\begin{array}{l}\text { Początek działania: } 12 \text { godz.; } \\
\text { pełna skuteczność: po } 72 \text { godz. } \\
\text { Zakończenie działania: } 12 \\
\text { godz. po odstawieniu }\end{array}$ \\
\hline & Roztwór & Dożylnie & & $\begin{array}{l}\text { Leczenie silnego bólu w warun- } \\
\text { kach szpitalnych, gdy koniecz- } \\
\text { na jest szybka ulga w bólu }\end{array}$ \\
\hline & Aerozol do nosa & Donosowo & & Ból przebijający \\
\hline & Tabletki & $\begin{array}{l}\text { Podjęzykowo lub } \\
\text { przezpoliczkowo }\end{array}$ & & Ból przebijający \\
\hline & $\begin{array}{l}\text { Pastylka do ssa- } \\
\text { nia/Lizak }\end{array}$ & $\begin{array}{l}\text { Przezpoliczkowo, } \\
\text { przezśluzówkowo }\end{array}$ & & Ból przebijający \\
\hline
\end{tabular}


Tabela 1 cd. Drogi podawania leków i wskazania do stosowania opioidów [8, 15-18 ]

\begin{tabular}{|c|c|c|c|c|}
\hline Opioid & Formuła & Droga podania & Wskazania & Komentarze \\
\hline \multirow{3}{*}{$\begin{array}{l}\text { Buprenor- } \\
\text { fina }\end{array}$} & Plastry & Przez skórę & \multirow{3}{*}{$\begin{array}{l}\text { Ból, zwłaszcza z czynnikiem } \\
\text { neuropatycznym (także u } \\
\text { pacjentów z zaburzeniami } \\
\text { czynności nerek i dializo- } \\
\text { wanych) }\end{array}$} & \multirow{3}{*}{$\begin{array}{l}\text { Uzależnienie od opioidów u } \\
\text { osób uzależnionych }\end{array}$} \\
\hline & Roztwór & Dożylnie & & \\
\hline & Tabletka & Podjęzykowo & & \\
\hline \multirow[t]{2}{*}{ Oksykodon } & $\begin{array}{l}\text { Tabletki o zmo- } \\
\text { dyfikowanym } \\
\text { uwalnianiu }\end{array}$ & Doustnie & Ból & \multirow[t]{2}{*}{$\begin{array}{l}\text { Mniej skutków ubocznych niż } \\
\text { morfina }\end{array}$} \\
\hline & Roztwór & $\begin{array}{l}\text { Dożylnie, ED, } \\
\text { dokręgosłupowo }\end{array}$ & & \\
\hline $\begin{array}{l}\text { Oksyko- } \\
\text { don/ } \\
\text { Nalokson }\end{array}$ & $\begin{array}{l}\text { Tabletki o zmo- } \\
\text { dyfikowanym } \\
\text { uwalnianiu }\end{array}$ & Doustnie & $\begin{array}{l}\text { Ból u pacjentów z zapar- } \\
\text { ciem opioidowym, opornym } \\
\text { na środki przeczyszczające }\end{array}$ & \\
\hline Tapentadol & $\begin{array}{l}\text { Tabletki o natych- } \\
\text { miastowym uwal- } \\
\text { nianiu i tabletki o } \\
\text { zmodyfikowanym } \\
\text { uwalnianiu }\end{array}$ & Doustnie & $\begin{array}{l}\text { Ból, szczególnie w przypad- } \\
\text { ku czynnika neuropatycz- } \\
\text { nego }\end{array}$ & \\
\hline Petydyna & Roztwór & $\begin{array}{l}\text { Dożylnie, domię- } \\
\text { śniowo, podskór- } \\
\text { nie }\end{array}$ & & $\begin{array}{l}\text { Działanie parasympatolityczne } \\
\text { w bólu występującym w prze- } \\
\text { biegu kolki } \\
\text { Metabolizowane do neurotok- } \\
\text { sycznej norpetydyny (nie do } \\
\text { stosowania przewlekłego) }\end{array}$ \\
\hline Metadon & Syrop, tabletka & Doustnie & $\begin{array}{l}\text { Uzależnienie od innych me- } \\
\text { tod leczenia opioidami, ból } \\
\text { umiarkowany do silnego } \\
\text { (skuteczny w bólu neuropa- } \\
\text { tycznym), kaszel }\end{array}$ & $\begin{array}{l}\text { Metabolizm i duże indywidual- } \\
\text { ne zróżnicowanie T1/2 - ko- } \\
\text { nieczne jest staranne miarecz- } \\
\text { kowanie. } \\
\text { T1/2 dawki pojedynczej = 4-6 } \\
\text { godz. przy podawaniu pozaje- } \\
\text { litowo, } 12-18 \text { godz. doustnie; } \\
\text { dawki powtarzane = 12-48 } \\
\text { godz. [1]. } \\
\text { Dobra alternatywa dla pacjen- } \\
\text { tów otrzymujących wysokie } \\
\text { dawki opioidów [2] }\end{array}$ \\
\hline
\end{tabular}

- pacjenci zażywający opioidy nie powinni prowadzić pojazdów.

Czynniki ryzyka wystąpienia uzależnienia psychicznego od opioidów:

- przypadki nadużywania substancji przez pacjenta lub członka rodziny w wywiadzie;

- młody wiek;

- problemy z prawem w przeszłości;

- środowiska wysokiego ryzyka;

- problemy z pracodawcami, rodziną i przyjaciółmi w przeszłości;

- skłonności do podejmowania ryzyka i/lub do poszukiwania silnych wrażeń;

- palenie papierosów i stosowanie używek;

- depresja i/lub lęki w przeszłości;

- doświadczenie przemocy w dzieciństwie w wywiadzie;

- liczne czynniki stresogenne [23].
Długotrwałe przyjmowanie opioidów może prowadzić do rozwoju tolerancji na analgetyczny efekt opioidów, któremu towarzyszy powolny rozwój tolerancji na działania niepożądane [24]. Tolerancji na działanie opioidów można zapobiec poprzez jednoczesne przyjmowanie ketaminy [25].

\section{Opioidy o podwójnym mechanizmie działania}

Tapentadol pełni funkcję agonisty receptorów opioidowych typu $\mu$ w OUN i inhibitora wychwytu zwrotnego noradrenaliny w zstępującym układzie antynocyceptywnym i dlatego jest pomocny zarówno w leczeniu bólu nocyceptywnego, jak i neuropatycznego. Tapentadol nie wymaga aktywacji metabolicznej, ponieważ występuje tylko w jednym enancjomerze. 
Tabela 2. Efekty jednoczesnego stosowania opioidów z doustnymi inhibitorami płytkowego receptora P2Y12 [19, 20]

\begin{tabular}{|c|c|c|c|c|c|}
\hline Lek & Działanie & Aktywacja & $\begin{array}{l}\text { Siła } \\
\text { działania }\end{array}$ & Wskazania & $\begin{array}{l}\text { Wpływ równoczesnego } \\
\text { stosowania z morfiną } \\
\text { na biodostępność }\end{array}$ \\
\hline Klopidorgel & Przedlek & $\begin{array}{l}\text { Hydroliza przez } \\
\text { esterazy do nie- } \\
\text { aktywnego ( } 85 \%) \\
\text { metabolitu, reszta } \\
(15 \%) \text { - dwa } \\
\text { etapy w wątrobie } \\
\text { przez CYP2C19 } \\
\text { i CYP2C19- } \\
\text { główny i paraok- } \\
\text { sonaza-1 (PON-1) } \\
\text { - drugorzędny }\end{array}$ & + & $\begin{array}{l}\text { Dusznica bolesna nie- } \\
\text { stabilna } \\
\text { Zawał serca bez unie- } \\
\text { sienia odcinka ST w po- } \\
\text { łączeniu z aspiryną } \\
\text { Zawał serca z uniesie- } \\
\text { niem odcinka ST } \\
\text { Świeży zawał serca } \\
\text { Udar } \\
\text { Obwodowa choroba } \\
\text { naczyń krwionośnych }\end{array}$ & $\begin{array}{l}\text { Nieodwracalny inhibitor } \\
\text { Morfina spowalnia wchła- } \\
\text { nianie klopidogrelu, obniża } \\
\text { stężenie aktywnego metabo- } \\
\text { litu w osoczu o } 34 \% \text {, opóźnia } \\
\text { i zmniejsza wpływ klopidogre- } \\
\text { lu na płytki krwi u zdrowych } \\
\text { ochotników }\end{array}$ \\
\hline Prasugrel & Przedlek & $\begin{array}{l}\text { Hydroliza przez } \\
\text { esterazy, następ- } \\
\text { nie jeden etap } \\
\text { w wątrobie przez } \\
\text { CYP3A4, CYP2B6. } \\
\text { CYP2C19, CYP2C9 } \\
\text { oraz } \\
\text { CYP2D6 }\end{array}$ & ++ & $\begin{array}{l}\text { Ostry zespół wieńcowy. } \\
\text { Dusznica bolesna } \\
\text { Zawał serca }\end{array}$ & $\begin{array}{l}\text { Nieodwracalny inhibitor. } \\
\text { Morfina obniżyła maksymalne } \\
\text { stężenie w osoczu metabo- } \\
\text { litu prasugrelu aktywnego } \\
\text { o } 31 \% \text { i opóźniła rozpoczęcie } \\
\text { maksymalnego zahamowania } \\
\text { formowania się czopu płytko- } \\
\text { wego o } 10 \text { min }\end{array}$ \\
\hline Ticagrelor & Aktywny & & +++ & $\begin{array}{l}\text { Ostry zespół wieńcowy. } \\
\text { Zawał mięśnia serco- } \\
\text { wego. } \\
\text { Incydenty sercowo-na- } \\
\text { czyniowe }\end{array}$ & $\begin{array}{l}\text { Odwracalny inhibitor } \\
\text { Morfina zmniejsza i opóźnia } \\
\text { efekty działania ticagreloru, ale } \\
\text { nie wydaje się obniżać działania } \\
\text { przeciwpłytkowego u zdrowych } \\
\text { ochotników. Morfina opóźnia } \\
\text { wchłanianie ticagreloru i jego } \\
\text { aktywny metabolit o 1h oraz } \\
\text { obniża poziom ticagreloru } \\
\text { i jego aktywnego metabolitu } \\
\text { w osoczu o 25-31\% }\end{array}$ \\
\hline
\end{tabular}

Tramadol jest antagonistą receptora opioidowego typu $\mu$, o mniejszym powinowactwie wobec receptorów typu $\delta$ i $\kappa(40 \%$ aktywności). Ponadto, blokuje wychwyt serotoniny i noradrenaliny w rdzeniu kręgowym (60\% aktywności). W przeciwieństwie do tapentadolu, jest on metabolizowany w wątrobie do O-desmetylotramadolu. Jest on zasadniczo bezpieczny i skuteczny, jednak jednoczesne stosowanie metoklopramidu może spowodować wystąpienie napadów. W przypadku dużych dawek tramadol może również powodować wystąpienie zespołu serotoninowego.

\section{Opioidy „w pigułce" i kontrowersje wokół stosowania wybranych opioidów}

Kodeina powstaje poprzez metylowanie morfiny, jest obecna w niewielkich ilościach w opium. Wykazuje 10-krotnie słabsze działanie przeciwbólowe niż morfina, ponieważ około $10 \%$ jest demetylowane w wątrobie do morfiny, która powoduje właściwą analgezję. Kodeina działa przede wszystkim przeciw- kaszlowo oraz w niewielkim stopniu uspokajająco i przeciwbólowo poprzez receptor typu $\mu$ (MOR) w mózgu. Wskazania do leczenia kodeiną obejmują suchy, uporczywy kaszel i umiarkowany ból. Ze względu na zahamowanie odruchu kaszlu nadaje się raczej do leczenia kaszlu suchego [26]. Co ciekawe, skuteczność kodeiny w leczeniu kaszlu u chorych na POChP nie jest większa niż w przypadku stosowania placebo [27].

Kodeina, w połączeniu z analgetykami nieopioidowymi, takimi jak paracetamol, aspiryna lub ibuprofen, może wykazywać znacznie silniejsze działanie przeciwbólowe. Wykazano, że kodeina/paracetamol u dorosłych jest skuteczna i bezpieczna w przypadku ostrego i przewlekłego bólu nocyceptywnego, jak również u pacjentów z urazami. Szczególną ostrożność należy zachować w przypadku pacjentów pediatrycznych, ponieważ kodeina może być podawana wyłącznie dzieciom powyżej 12. roku życia. W przypadku stosowania kodeiny/paracetamolu w tonsillektomii należy ocenić ryzyko wystąpienia polimorfizmu genetycznego (CYP450) na podstawie metabolizmu kodeiny związanego z CYP450 i jego zmienności genetycznej [28]. 
Dihydrokodeina (DHC) to półsyntetyczny analog kodeiny, o działaniu 2-krotnie silniejszym niż kodeina, jeśli jest stosowany pozajelitowo, i nieco silniejszym w przypadku stosowania doustnego. W porównaniu z morfiną, dihydrokodeina jest 6-krotnie słabsza [29]. Dihydrokodeina należy do grupy słabych opioidów stosowanych na ból od łagodnego do umiarkowanego (stopień 2 drabiny analgetycznej WHO). Odgrywa ona rolę w leczeniu umiarkowanego, przewlekłego bólu, a także kaszlu, biegunki i uzależnienia od opioidów [30, 31]. Charakteryzuje się lepszą analgezją, zmniejszonymi objawami: zmęczenia, zaburzeń snu, nudności, wymiotnymi, oraz lepszym apetytem w porównaniu z tramadolem [32]. W niektórych badaniach pojedyncze dawki $30 \mathrm{mg}$ i $60 \mathrm{mg}$ dihydrokodeiny nie zapewniły pożądanej analgezji w bólu pooperacyjnym, natomiast ibuprofen $w$ dawce $400 \mathrm{mg}$ zapewniał analgezję statystycznie lepszą [33]. Dihydrokodeina jest również centralnie działającym czynnikiem zmniejszającym odruch kaszlu, skutecznym w łagodzeniu kaszlu u pacjentów z nowotworem płuc [34].

Morfina. Działanie morfiny może być modyfikowane przez jednoczesne podawanie diklofenaku i innych leków wpływających na UGT2B7 (enzym uczestniczący w glukuronizacji morfiny - głównego szlaku metabolicznego leku). Drugi szlak metabolizmu morfiny odbywa się za pośrednictwem CYP2D6, dlatego substraty enzymu (amitryptylina, duloksetyna, haloperydol, metoklopramid, ondansetron, oksykodon, paroksetyna, risperidon, sertralina, tamoksyfen, tramadol, trazodon, wenlafaksyna) mogą wpływać na skuteczność morfiny. Inhibitory CYP2D6 (amiodaron, fluoksetyna, haloperidol, metadon, paroksetyna, sertralina) mogą zwiększyć ryzyko wystąpienia działań niepożądanych. Znaczenie kliniczne wyżej wymienionego zagadnienia jest nieznane.

W wielu badaniach odnotowano zwiększone ryzyko umieralności u pacjentów z niewydolnością serca otrzymujących morfinę [36-37]. Morfina wykazuje działanie przeciwbólowe u pacjentów z zawałem serca, a także obniża ciśnienie krwi i średnie ciśnienie tętnicze mierzone na tętnicy ramiennej u tych pacjentów. Rejestr CRUSADE wykazał wyższą częstość występowania działań niepożądanych u pacjentów z ostrymi zespołami wieńcowymi (NSTEACS) leczonych klopidogrelem i jednocześnie morfiną dożylną [38]. $\mathrm{U}$ pacjentów z zawałem serca $\mathrm{z}$ uniesieniem odcinka ST morfina nie wiązała się ze znaczącym wzrostem częstości występowania poważnych, niepożądanych zdarzeń sercowych (MACE) [39]. Jednak istotne interakcje mogą wystąpić w przypadku jednoczesnego stosowania tikagreloru $[40,51]$. Ponadto, następuje spowolnione opróżnianie żołądka, co może skutkować opóźnionym wchłanianiem klopidogrelu [42].
$U$ chorych z obrzękiem płuc wykazano, że morfina wpływa na 30-dniową śmiertelność [36, 37, 43-45]. Vozoris i wsp. wykazali zwiększoną liczbę powikłań oddechowych oraz śmiertelność u pacjentów z POChP [46]. Niemniej jednak, morfina poprawiła czynność oddechową i tolerancję wysiłku u tych chorych [47].

Oksykodon, agonista receptorów mu i kappa (skuteczność $w$ bólu wisceralnym) jest substratem receptorów CYP3A4 (główny) i CYP2D6 (drugorzędny) i dlatego może wchodzić w interakcje lekowe. Oksykodon może być stosowany wraz z morfiną i hydromorfonem jako opioid pierwszego rzutu $w$ leczeniu umiarkowanego do silnego bólu u pacjentów chorych na nowotwory [48-50]. Ponadto, oksykodon jest zalecany w leczeniu ostrego bólu pooperacyjnego [51]. W przypadku zaburzeń czynności wątroby lub nerek należy zmniejszyć dawki oksykodonu.

Buprenorfina, częściowy agonista receptorów mu, agonista ORL-1 i antagonista receptorów beta. Jednak w dawkach terapeutycznych buprenorfina działa jak agonista receptora opioidowego, ponieważ $w$ dawkach do $32 \mathrm{mg}$ na dobę nie występuje efekt pułapowy analgezji [52]. Ze względu na rozległą glikuronizację i znacznie mniejszy metabolizm CYP3A4, buprenorfina ulega efektowi pierwszego przejścia i charakteryzuje się niewielkim ryzykiem wystąpienia interakcji lekowych. Jednakże jednoczesne podawanie haloperydolu, lewomepromazyny lub środków przeciwnadciśnieniowych może powodować niedociśnienie. Inne opioidy (agoniści receptorów mu) mogą zwiększać efekt przeciwbólowy buprenorfiny. Buprenorfina nie jest zalecana w leczeniu ostrego lub przerywanego bólu u pacjentów, którzy nie byli do tej pory leczeni opioidami [25]. Buprenorfina wykazuje korzystny efekt pułapowy w przypadku depresji oddechowej, w wyniku czego depresja oddechowa występuje jedynie przy stosowaniu dużych dawek.

Tapentadol wykazuje podwójny mechanizm dziatania; funkcjonuje jako agonista receptora opioidowego typu $\mu$ (MOR) w OUN i inhibitor wychwytu zwrotnego noradrenaliny $w$ zstępującym układzie antynocyceptywnym, a zatem jest pomocny zarówno w leczeniu bólu nocyceptywnego, jak i neuropatycznego. Tapentadol nie wymaga aktywacji metabolicznej, ponieważ występuje tylko w jednym enancjomerze.

Metadon jest metabolizowany przez CYP3A4 i CYP2B6, dlatego inhibitory enzymów (amiodaron, klarytromycyna, diklofenak, diltiazem, flukonazol w dużej dawce, haloperydol, werapamil lub/i klopidogrel, fluoksetyna, sertralina) mogą zwiększyć ryzyko toksyczności leku. Induktory enzymów (karbamazepiny, klonazepamu, deksametazonu, fentanylu, haloperidolu, ketaminy, midazolamu, omeprazolu, oksykodonu, risperidonu, wenlafaksyny, diklofenaku, ketaminy) mogą zmniejszać skuteczność metadonu. 
W metabolizmie metadonu uczestniczą również CYP1A2 i CYP2D6, ale w mniejszym stopniu. Ostatnio odkryto związek między stosowaniem metadonu, a występowaniem arytmii, czyli częstoskurczu komorowego (VT). Głównym mechanizmem występowania częstoskurczu komorowego jest wydłużenie QT, dlatego podawanie metadonu musi być poprzedzone korektą zaburzenia gospodarki elektrolitowej. Jeżeli spodziewana dzienna dawka przekroczy $100 \mathrm{mg}$ doustnie, zaleca się monitorowanie elektrokardiograficzne [53].

\section{Wnioski}

1. Prawidłowe miareczkowanie dawki opioidów jest kluczowe dla uniknięcia depresji oddechowej wywoływanej przez te leki.

2. Buprenorfina $\mathbf{w}$ dawce terapeutycznej działa jako agonista receptora opioidowego typu $\mu$ i może być podawana jednocześnie $z$ innymi agonistami receptora opioidowego typu $\mu$.
3. Jednoczesne podawanie ketaminy z opioidami zmniejsza zapotrzebowanie na opioidy, co powoduje konieczność zmniejszenia dawek opioidów i zapobiega rozwojowi tolerancji na opioidy.

4. W przypadku zaburzeń czynności nerek należy stosować fentanyl, buprenorfinę lub metadon.

5. Preparaty morfiny do stosowania miejscowego (roztwór, żel, gaza, aerozol) mogą zminimalizować ryzyko wystąpienia ogólnoustrojowych działań niepożądanych. W przypadku stosowania na dużych powierzchniach skóry, ran lub błon śluzowych, morfina może powodować sedację.

6. Interakcje między lekami oraz pomiędzy lekami a żywnością (sok grejpfrutowy) powinny być brane pod uwagę u pacjentów otrzymujących jednocześnie środki psychoaktywne działające na OUN, IMAO, leki antypsychotyczne i ksenobiotyki metabolizowane przez CYP450 i glikoproteinę P.

7. Opóźnienie w opróżnianiu żołądka spowodowane opioidami może ograniczyć lub zniwelować działanie leków przeciwpłytkowych. 